УДК 342.365:342.156:342.514

DOI https: / / doi.org/10.32837/yuv.v0i3.1906

\author{
В. Мельник, \\ кандидат политических наук, \\ ассистент кафедры политологии \\ Киевского национального университета имени Тараса Шевченко, \\ преподаватель кафедры философии и общественных наук \\ Винницкого национального медицинского университета \\ имени Н.И. Пирогова, \\ главный редактор журнала «Анналы юридической истории»
}

\title{
ПОЛИТИКО-ПРАВОВОЙ СТАТУС ИМПЕРАТОРА ВОСТОЧНОЙ РИМСКОЙ ИМПЕРИИ В VI ВЕКЕ: ТИТУЛ, ЮРИСДИКЦИЯ И СУБЪЕКТНОСТЬ
}

K началу VII-го века нашей эры кризис античных социальных отношений не был ощутимым, а военно-политическая мощь Восточной Римской империи, основы которой заложил император Юстиниан Великий (527-565), позволяла Византии чувствовать себя как никогда уверенно [1, с. 258-259]. Мелкие противостояния с отдельными варварскими народами успешно локализовывались использованием древней римской тактики «разделяй и властвуй!» [2, с. 234-236], поскольку всем исследователям хорошо известно, что вожди бунтующих племен никогда не хотели подчиняться не только высшей императорской власти в блистательном Константинополе, но и даже королевской власти своих малоизвестных окружающему миру «рексов» [3, Procop. $B G$, II, 37-40].

Император Восточной Римской империи в 600 году являлся истинным «царем царей» христианского сообщества стран Евразии. На протяжении нескончаемых земель днепровской или дунайской равнины, варварской «лесной» Европы, Северной Африки, Ближнего Востока, включая Аравию и Кавказ, ни один властитель не мог считать свою власть законной и защищенной, если он не получил на это официальную юридическую санкцию императора [4, с. $7,11,19-23$ etc.; 5, с. 30-31]. Согласно устоявшейся во времена принципата (27 г. до н. э. - 284 г. н. э.) и домината (284-480 гг. н. э.) норме римского публичного права только властелин Нового Рима (Константинополя) мог решать, кому присвоить королевское (царское) достоинство, а кого лишить этого титула [3, Procop. BG, I, 1.10-11; 6, Anon. Vales., XI, 49; 7, Iord. Getica, 291-292].

На санкционированных Константинополем королей сыпались не только формальные знаки уважения со стороны императорского дворца и мощного бюрократического аппарата империи. Перспектива мирного сосуществования с соседними народами для таких королей считалась прочнее и гораздо увесистее, ведь мало кто осмеливался нападать на императорских королей («рексов») и объявлять войну великой Византии [3, Procop. BG, II, 14.10-11, 26-30].

Ход истории VI века с момента Рождества Христового продемонстрировал всем народам мира жизненную силу римских политических традиций, устойчивость теории и практики социального мировоззрения, построенных на фундаменте римского частного и публичного права [1, с. 14; 2 , с. $88-97 ; 8$, с. $33-36$ ]. 


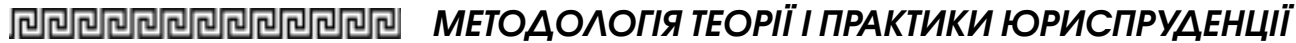

Юстиниан Великий (527-565), осуществивший в 529-550-х гг. кодификацию древнего римского законодательства, сумел добиться не только формально-юридического, но и утилитарно-политического признания власти восточно-римских императоров от «рексов» со среды варварских племен Северной Африки, Италии, Испании, Бургундии, Лангобардии, Франкии, Антского союза [1, с. 251, 259; 9, с. 3-12]. При Юстиниане военный механизм Византии являлся достаточным основанием для соблюдения варварскими королями («рексами») широких прав латиноязычного большинства в странах Западной Европы [10]. При помощи Юстиниана «железная рука» полководца Нарсеса удерживала порядок в Италии, провозглашенной «личной исторической собственностью императора» [11, Nov. Just., 69; 70; 73; 75; 80; 89; 91; $101 ; 104 ; 104 ; 106]$.

Короли (правильно - «рексы») варварских племен Европы, бывшие политическими хозяевами Западной части Римской империи в течение $\mathrm{V}$ века, после падения вандало-аланского Карфагенского королевства в 534 г. и разгрома Нарсесом остготов, алеманнов, бургундов и франков в 552-554 гг. потеряли чувство безопасности и безнаказанности [3, Procop. BG, IV. 26.4; 12, Agath., I.6]. Так, уже в дипломатической переписке поверженных Нарсесом остготских вождей и слабеющих франкских королей из династии Меровингов (правила Галлией в 476-751 гг.) вскрывается основополагающий фактор страха варварских руководителей перед полномасштабным вторжением и завоеванием армией Восточной Римской империи обретённого франками пространства Галлии, а следовательно и прилегающих этнотерриториальных ареалов алеманнов, саксов, тюрингов, баваров и фризов (так называемой римскими географами «Германии» [13, c. 131-134]).
Меровингские короли, по свидетельству хрониста Агафия Миринейского, понимали, что «у византийцев не будет недостатка в законных поводах» для развязывания войны против слабеющей Франкии. Кроме того, остготские послы при меровингском дворе подчеркивали: «Восточные римляне будут прикидываться не завоевателями, а ведущими справедливую войну, не ищущими чужого, но возвращающими владения своих римских предков» [12, Agath., I. 5].

Впрочем, ни в Северной Африке, ни в Италии, ни в Испании, где в 554 г. высаживались императорские контингенты Юстиниана Великого, византийцам не приходилось «прикидываться» [3, Procop. BG, I, 5. 12-18]. Везде они были с почетом встречены местной аристократией, представителями знатных сенаторских и региональных династий, романским зажиточным крестьянством и торгово-ремесленной средой западноевропейских городов.

Подчеркнем, что экспедиционную армию Нового Рима особенно приветствовали торговцы и ремесленники, получившие благодаря политике Юстиниана возможность возобновить полноценное внутри имперское морское сообщение, не боясь угрозы вандальских пиратов. Юстиниан вновь сделал Средиземное море «внутренним морем римлян» [14, с. 127], как это было во времена правления Феодосия Великого (379-395) или даже при Константине Святом (306-337).

В 550-е гг. появилось всеобщее понимание и одобрение свершившейся реинтеграции западноевропейских провинций [15, р. 389-409]. Корабли, наполненные разнообразными товарами, могли вновь отплывать из гаваней Гадеса, Тингиса, Никеи Провансальской (Ниццы), Остии, Неаполя, Сиракуз, Гидрунта и даже Карфагена. Все «обстоятельные» портовые города Средиземного моря к 567-му году оказались под крепким контролем вооруженных 
сил Восточной Римской империи [16, с. 157-158].

Морская торговля была призвана не столько упрочить экономическое благосостояние западноевропейских провинций, разрушенных нерадивым варварским правлением, сколько возобновить информационный и культурный обмен - коммуникацию между жителями Западной и Восточной частей Римской империи ${ }^{1}$. Напомним, что именно военное нарушение средиземноморской коммуникации, веками обустраивавшей античный быт финикийцев, греков и римлян, привело в 428-468 гг. стараниями алано-вандальского короля Гензериха (428-477) к политическому упадку Западной Римской империи [2, с. 185].

Институты императорской власти в Западной Европе были нивелированы вандало-аланским вторжением в пределы Северной Африки $[17$, с. 74$]$. Заняв Гипон и Карфаген, основав пиратские базы на Балеарских островах, на Сицилии, Сардинии и Корсике, вандалы начали грабить все грузы, шедшие на огромном пространстве Западного Средиземноморья и даже достигали «канонических» прибрежных вод восточно-римской Эллады. Плавать морем тогда стало небезопасно, а использовать пешие торговые пути - дорого и нерентабельно [18, с. 63-108].

Долгий переход из испанской Севильи (Испалиса) в Константинополь (Новый Рим) нёс за собой такое количество денежных расходов, выплат таможенных сборов новоявленным королькам («рексам») Западной и Центральной Европы, что использовать его для получения материально-денежной выгоды не имело никакого смысла. K тому же пеший переход гораздо меньше был застрахован от грабительских поползновений «несистемных» варваров, которые очень часто не слушали своих королей и кровно враждовали друг с другом. То есть, всё те же пороки, которые веками отравляли римскую политическую жизнь, проявлялись еще ярче и менее завуалированно в социально-экономическом строе варваров.

Отсутствие централизма и чиновничьего аппарата, адекватных ситуации Великого переселения народов (III - VII вв.), делало германских и остальных варваров, оккупировавших пространства Западной части Римской империи, внутренне слабым и одолеваемым противоречиями сообществом, неспособным получать дивиденды от возобновленной внутриримской торговли.

Малообразованные варварские короли даже представить себе не могли, какую прибыль им способна была дать непрекращающаяся пешая и морская торговля римлян Запада с римлянами Востока [19, р. 919; 20, Lex Visigothorum IX, 1, 9; VII, $3,3 ; \mathrm{VI}, 2,1 ; \mathrm{V}, 4,21]^{2}$. Одни только налоги и таможенные сборы могли бы сделать из франкских, алеманнских, тюрингских, лангобардских королей богатейших властителей, способных не бояться угроз со стороны римских императоров Константинополя. Но именно традиционное и вполне нормальное для поздней Античности невежество правителей варварских племен, их непонимание тонкостей экономической политики, ущемление будничной и любимой римлянами возможности торговать привело

\footnotetext{
1 Термины «Западная часть Римской империи» и «Восточная часть Римской империи» употребляются нами в понимании нормы, легализованной императорским Эдиктом Феодосия от 395 г., когда сложилась формула «одна страна - две части», позволившая его сыновьям избежать кровавой борьбы за престол и одновременно считаться полноценными императорами единой Римской империи при условии территориального принципа раздела их полномочий
}

2 Вестготская правда доказывает, что поставки рабов из вестготской Испании в Восточную часть Римской империи не прекращались: Lex Visigothorum IX, 1, 9; VII, 3, 3; VI, 2, 1; V, 4, 21 


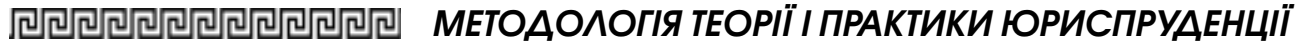

к «реконкисте VI века» - возобновлению Юстинианом политической власти Нового Рима в провинциях Западной части Римской империи [21, с. 44-59].

Юридическая власть восточно-римских императоров была признана варварскими королями еще при Зеноне Исавре (476-491). Когда малопочтенный в варварских кругах, последний западно-римский император Юлий Непот (476-480) умер [22, с. 60-66], скирский рекс Италии Одоакр признал над собой высшую власть Зенона (в том же 480-м году) [23, с. 29-30]. В обмен на сохранение формального суверенитета над итальянской обителью римской культуры Зенон обязался не вмешиваться во внутреннюю политику Одоакра [23, с. 30]. Аналогичные клятвы верности римскому императору далекого Константинополя принесли парижский дукс Галло-романского домена Афраний Сиагрий [24, р. 238], вестготский король Испании Эврих [17, с. $55 ; 25$, с. $125-130]$, остготский король Паннонии Теодорих Великий из династии Амалов [2, с. 61].

Гораздо крепче оказался высший сюзеренитет, осуществляемый наследником Зенона Исавра - императором Анастасием I (491-518) [26, с. 67-69]. 27 лет правил Анастасий Византией и сумел добиться признания своей высшей власти не только от подчиненных Константинополю остготов Италии и Паннонии, вестготов Испании, но и принял верховную власть над дотоле бунтующими вандало-аланами в Северной Африке ${ }^{3}$ и оккупировавшими Галло-романский домен и Аквитанию франками [27, Cregoire de Tours, Histoire des Francs, II. 38].

Рекс франков Хлодвиг из династии Меровингов даже получил в 507 г. венок власти из рук легатов Анастасия, был провозглашен императорским наместником Галлии [17, с. 290]. Впоследствии этого титула от послов Константинополя добивались все менее удачливые наследники воинственного Хлодвига - Меровинги разного качества и количества, раздробившие и унизившие мощную Хлодвигову Франкию [12, Agath., I. $6 ; 28$, с. 182-195].

В 553-554 гг. войска рекса Теодебальда (548-555), одного из них, были разбиты византийским полководцем Нарсесом [4, с. 423-438], после чего династия Меровингов вплоть до её бесславного падения в 751 г. [29, с. 45] числилась в роли третьестепенных, наименее цивилизованных вассалов Константинополя. Даже гассанидским арабам Аравийской пустыни [2, с. 255], верблюжьим наездникам, живущим в кибитках отдавалось больше почтения послами Константинополя, нежели франкам под властью опозорившихся Меровингов.

После серии поражений от Нарсеса, различных вестготских комитов (военачальников), бретонцев, басков, фризов и воинственных саксов франки на какое-то время перестали быть реальной угрозой византийскому политическому владычеству в Европе. Формально занятая франками Галлия считалась законной территорией Восточной Римской империи (Византии) [24, p. 242].

Зенон Исавр (476-491) стал первым истинно византийским правителем всей Римской империи, если не считать не менее «византийских» по выдающемуся уровню культурной политики императоров блестящего IV века Диоклетиана (284-305), Константина Святого (306-337), Феодосия Великого (379-395). Именно их

${ }^{3}$ В 500 г. императорский наместник Италии, а по совместительству остготский король Теодорих Великий (493-526) оккупировал Карфаген, предварительно заставив вандало-аланского короля Трасамунда (496-523) жениться на своей сестре Амалафриде (жила в 460-526 гг.). Признав власть восточно-римского (византийского) наместника Италии Теодориха, вандало-аланский правитель Северной Африки автоматически признал верховную власть Теодорихового сюзерена - восточно-римского императора 
предлагаем считать «троицей учредителей Византии», поскольку каждый из них приложил максимум усилий для обустройства Нового Рима (города Константинополя), для взаимной интеграции сенаторской аристократии западных и восточных провинций (с ощутимым преобладанием восточных аристократов и эллинистической полисной знати), для упрочения императорского статуса и установления специальной юридической техники опубликования императорских нормативно-правовых актов.

В.И. Уколова определяет: «Константинополь легитимизировал свой имперский статус как «Новый Рим», «Второй Рим». Причем это был не только и не столько политический лозунг или «исторический образ», предполагающий преемственность имперской традиции. В глазах подданных Восточной Римской империи, в широком ареале своего влияния Константинополь и был Римом, ибо еще в поздней античности самим римлянам было по существу безразлично, где конкретно находился центр или центры управления империей в Никомедии, Милане или Равенне. По выражению известного позднего римского поэта Рутилия Намациана, Рим «сделал весь мир Градом», то есть Град, Рим, был везде, и Град стал всем» $[5$, с. 30-31].

В условиях совершенно новой реальности, учитывая установление сюзеренной власти остготов Теодориха Амала (493-526) над Италией, Паннонией, Нориком, Испанией, югом Галлии и Провансом, Бургундией, Алеманнией, Тюрингией, Саксонией [2, с. 110], император Анастасий I (491-518) де-юре признавался «верховным владыкой мира» ещё более внушительным количеством бывших западно-римских провинций.

Очередной наследник трона Юстин I (518-527) ввязался в животрепещущие вопросы религии и культуры, взял под контроль мятежный римский епископат [26, с. 70-71].
Сделав многое для утверждения социально-политического положения ортодоксальной церкви, он наладил прекрасные отношения со всем варварским арианским сообществом, не разделяя Христианскую Ойкумену на конфессии и направления [4, с. 229].

Этот скорее политический (ни в коем случае не духовный!) компромисс, критикуемый внутри Константинопольской архиепископальной церкви, был одобрен многими иерархами западных провинций и позволил императору Юстину получать не только юридические (формальные), но и политические (реальные) выгоды от громкого статуса «императора всех христиан» [30, с. 52-53]. К примеру, участились публичные высказывания и клятвы Теодориха Амала о признании верности Юстину [2, с. 120]. Остготское войско шло в бой против пограничных варварских племен в Иллирии, Норике, Западной Паннонии с именем восточно-римского (византийского) императора на устах. Юстин чувствовал себя уже не столько юридической фикцией, сколько реальным символом римского единства.

Подчеркнем показательный факт, зафиксированный готским историком Иорданом. Несмотря на случившееся в 523-526 гг. охлаждение в дружбе Теодориха и Юстина, несмотря на планы римского сената по свержению остготской власти в Италии [31, с. 40-41], раскрытые и локализованные приспешниками династии Амалов, за несколько часов до своей смерти (30 августа 526 г.) Теодорих Великий, провозгласив своего внука Аталариха новым королем, приказал вождям и всему остготскому племени, «чтобы они охраняли и берегли короля, возлюбили сенат и римский народ, а императора восточного, храня всегда мир с ним и его благосклонность, почитали вторым после Бога» [7, Iord. Getica, 304].

Слова, сказанные самым могущественным человеком Западной 


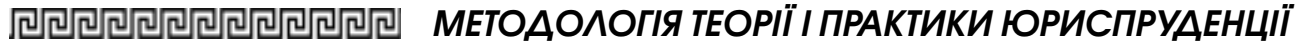

Европы, чего-то да стоят! Тем более, что Теодорих позаботился, чтобы его слова через надёжных послов дошли до ушей императора [4, с. 237].

Престолонаследник Юстина, его племянник Юстиниан Великий (527-565) в императорских нормативно-правовых актах именовал себя так: «Император Цезарь Флавий Юстиниан, владька Алеманнский, Готский, Франкский, Германский, Антский, Аланский, Вандальский, Африканский». Звучит внушительно, но традиционно в историографии считалось, что этот «терминологический экспансионизм» исходил исключительно со стороны технологии юридической формулировки, то есть не имел политического проявления и управленческого смысла.

Власть Юстиниана Великого впервые со времен Феодосия (379-395) охватила всё пространство обеих частей Римской империи целиком западной и восточной. Не опосредованно, а прямо состоялось признание власти Юстиниана испанскими вестготами, галльскими франками, германскими алеманнами и славянами-антами.

В 533-534 гг. усилиями полководца Велизария при активной военной и материальной помощи остготской регентши (526-534) и королевы (534-535) Амаласунты [3, Procop. BG, I, 3.22-24; Procop. BV, I, 14.5-6] Юстиниан завоевал Карфагенское королевство вандалов и аланов, подчинив своей прямой власти Северную Африку от Гибралтара до Киренаики [32, Cod. Just., I, 27; I, § 1-2; 33 , с. 18]. Тогда были впервые разведаны многие пустынные местности, захвачены оазисы, а византийские контингенты взяли власть над берберскими кочевьями и подчинили множество коренных мавританских племён, расположенных далеко к югу от средиземноморского побережья [34, p. 67-85].

Таким образом, в 533-534 гг. Юстиниан не только восстановил средизем- номорскую морскую торговлю и внутриимперскую линию коммуникаций [1, с. 246], но и подготовил почву для более глубокого освоения восточными римлянами Африканского континента [2, с. 188-192]. То, что в позднейших трудах европейских путешественников и миссионеров будет обозначено как «Чёрная Африка», первым начал всерьёз осваивать еще византийский император Юстиниан, используя масштабное фронтальное проникновение торговли, а через неё и культуры с христианской верой [35, с. 408].

Исконные африканские племена не воспринимались константинопольским двором в качестве объекта ассимиляции, а тем более физического истребления [36, s. 196-225]. Византийские купцы почтенно относились к африканским маврам, а имперская администрация Северной Африки предпринимала усилия для христианизации темнокожих жителей континента и набора их мужественных воинов в состав императорской армии [37, p. 287-320].

Кровопролитная война, длившаяся с 535-го по 552-й годы, приведшая к полному подчинению пространств Италии, Сицилии, Далмации, Прованса и Норика, была жутким испытанием для демографически уменьшающегося населения этих провинций [14, с. 131-138]. Однако именно уничтожение власти остготов на Апеннинах позволило Константинополю сполна воспользоваться плодами североафриканской победы 533-534 гг. [38, Marc. Chron., a. 535]. Ведь пиратство алланов и вандалов Юстиниан уничтожил, но для окончательного восстановления античных путей сообщения / снабжения официальному Константинополю были необходимы портовые города Италии, Галлии, Испании.

Кроме того, итальянские порты потенциально должны были приносить хороший доход императорской казне, чего, как показал опыт предыдущих 40 лет, не позволяли сделать 
плохо организованные и часто игнорируемые военными командирами («комитами») поборы остготских королей [39, с. 12-14].

Повод к итальянской войне Юстиниан избрал самый величественный и самый что ни на есть законный. Родственник-соправитель упомянутой выше королевы-наместницы Амаласунты по имени Теодат (534-536) арестовал её и предательски убил 30 апреля 535 года [7, Iord., Getica, 306; 38, Marc. Chron., a. 534; 40, Agn., 62; 41, Pauli Diac. Hist. Rom., XVI, 12]. Хронист Иордан пишет о дальнейших событиях: «Когда Юстиниан, император восточный, услышал о смерти Амаласунты, он был так огорчен, что счел убийство тех, кто был под его покровительством, личным оскорблением. В это самое время он одержал победу при помощи своего преданнейшего патриция Велизария над африканскими вандалами и, не задерживаясь, когда оружие было еще обагрено кровью вандалов, двинул войско против готов под командованием того же вождя» [7, Iord., Getica, 307].

Юстиниан, пребывавший в дружеских отношениях с Амаласунтой (дочерью Теодориха Великого) и верной сенаторской знатью, был благодарен Амаласунте за значительную военно-интендантскую помощь и размещение восточно-римского флота во время североафриканской кампании 533534 гг. Пользуясь своим суверенным правом верховного правителя западных римских провинций, он объявил Теодата узурпатором-убийцей, отбросил все остготские предложения мира и территориальных уступок, последовавшие в ответ [3, Procop. BG, I, 6.2] и ценой 17-летней войны полностью уничтожил «остготских бунтовщиков». Как известно, остготы не только навсегда исчезли с политической карты Европы, но и «расстворились» в этнокультурной среде латинской Италии [17, с. 68].

Весной 552 г. император Юстиниан также отреагировал на Севильский манифест самопровозглашенного вестготского рекса Атанагильда (551-567), призвавшего Юстиниана на помощь для совместной борьбы против бунтующего короля Агилы (549-554) [42, Isidori Historia Gothorum, 47].

K 550-му году вестготское владычество в Испании было достаточно крепким, но, как и в период существования Тулузского королевства вестготов Аквитании [17, с. 54-55], оккупированного франками в 507 г., основой подвластного сначала Теодориху Великому, а потом и византийским императорам политического порядка в Толедском королевстве вестготов Испании считалась прочная власть младшей ветви королевской династии Балтов [32, Cod. Just., I, 27, 2, § 2].

K Балтам относился победитель вандалов Валия (415-418), объединивший под властью вестготов большие части современных Франции и Испании [17, с. 54]. Балтом был и рекс Теодерих I (418-451), получивший от западно-римского императора Гонория (395-423) lex foedus на правление Тулузским королевством [17, с. 54]. В 507 г. франки Хлодвига убили в битве при Вуйе короля из династии Балтов Алариха II (484-507), чем развязали 5-летнюю западноевропейскую смуту [2, с. 104-110].

Проиграв войну Теодориху Великому, франки удержали под своей властью Аквитанию, получив lex foedus от восточно-римского императора Анастасия (491-518) [24, р. 242]. Теодорих Великий благодаря франкской оккупации вестготской Аквитании возвысился как никогда. Он выступил защитником «объединённого готского народа», оккупировал южную Галлию и взял под контроль всю Испанию. Его внук Амаларих в 511 г. стал рексом испанских вестготов [43, Chronicon Caesaraugustanum, a. 513].

До 526 г. Испания была полностью защищена остготами, но смерть Теодориха Великого (526 г.) пошатнула равновесие в западных провинциях Римской империи. Начались 


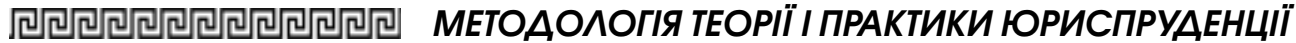

пограничные стычки с меровингскими франками, и уже в 531 г. Амалариха убил в Барселоне франкский шпион [27, Cregoire de Tours. Histoire des Francs. III. 10]. Этим печальным событием династическое правление Балтов среди вестготов пресеклось, по сути пресеклись и законные обещания невмешательства, предоставленные династии Балтов западно-римским императором Гонорием в соответствии с lex foedus от 418 года [17, с. 54-55]. Оруженосец Теодориха Великого и воспитатель Амалариха Теудис провозгласил себя королем, но с точки зрения римского публичного права это была чистой воды узурпация, требовавшая военного вмешательства восточно-римского императора [44, с. 211-213].

Во время правления узурпатора Теудиса в Испании (531-548 гг.) Юстиниан взял под полноценный контроль всю Северную Африку и большую часть Италии. Не ушла мимо глаз Юстиниана и военная помощь, оказываемая Теудисом бунтующему королю остготов Тотиле (541-552) [3, Procop. $B G$, II, 30]. В 548-549 гг. Испанию возглавлял лояльно относившийся к ортодоксальной церкви и правлению Юстиниана военачальник Теудигизел. Готская знать организовала его убийство, опасаясь обращения Теудигизела к Юстиниану Великому с просьбой о высадке военного контингента византийцев [7, Iord. Get., 303]. Королевский трон занял очередной узурпатор - Агила I (549-554), непримиримый арианин, желавший истребления латино-язычного ортодоксального населения полуострова.

В 551 г. в Севилье (древнем Гиспалисе) потомок тервингского причерноморского рода рексов-федератов по имени Атанагильд провозгласил себя альтернативным рексом Испании и обратился к императору Юстиниану Великому с просьбой о военной помощи против арианина-узурпатора Агилы [7, Iord. Get., 303]. Юстиниан в ответ отослал флот под командованием итальянского патриция Либерия, который помог разгромить войска Агилы. Патриций Либерий вновь возглавил созданную восточно-римскую провинцию Спания [45, с. 33-34]. Вестготы Испании получили от Юстиниана lex foedus на Толедские (древние тараконские) земли, а Бетика (издревле колонизированная эллинами, финикийцами-карфагенянами и римлянами) перешла под непосредственный контроль императорских чиновников и налоговой службы (фиска). Кадис, Севилья, Кордова, Малага, Картахена уже политически, а не только юридически, вошли в состав Восточной Римской империи [46, p. 77].

Как и прежде, в случае с «реконкистой» (отвоеванием) Испании Юстиниан ни разу не вышел «за рамки дозволенного», постоянно находясь в законодательном поле римского публичного права [32, Cod. Just. I, 27, 2]. Именно юридические аргументы позволяют нам признать все три «отвоевательные» кампании Юстиниана (африканскую 533-534 гг., итальянскую 535-554 гг., испанскую 552-554 гг.) не «завоеванием» или «аннексией» новых земель, а «восстановлением справедливого порядка», «таксиса», «гармонии». Юстиниан считал их торжеством «непогрешимой древности» $[1$, с. 241]. Так, еще Прокопий Кесарийский подчеркнул: «Естественная задача императора желание расширить империю и сделать ее более славной» [3, Р госор. $B P, \mathrm{I}, 3]$.

Не состоялось «аннексии» как «насильственного присоединения страны или части её к другой стране» [47, с. 97-106], поскольку африканские и западноевропейские провинции были возвращены в состав «своей» страны. Скорее, состоялась деоккупация или национализация земель ранее находившихся во временном пользовании варваров (согласно lex foedus). Поскольку варварские короли федератов неоднократно нарушили 


\section{ЮРИАИЧНИЙ ВІСНИК, 2020/3}

нормы предоставленного им милостью предыдущих императоров lex foedus, то император Юстиниан получил законный повод наказать преступников, убивших назначенных им законных наместников (к примеру, Теодата, убившего королеву Амаласунту в Италии), наказать узурпаторов власти (Агилу в Испании, Витигиса и Тотилу в Италии, Теодебальда в Галлии), наказать притеснителей ортодоксальной церкви (Агилу в Испании, Гелимера в северо-африканском Карфагене).

Императорская армия Юстиниана не вела «войны» в юридическом смысле этого слова [48]. Обратимся к лексикографическому наследию. Владимир Даль (1801-1872) так характеризовал интересующее нас понятие: «Война - раздор и ратный бой между государствами; международная брань» [49, с. 91]. Такое же понимание «войны» сохранилось в современной юридической науке. Спросим: была ли борьба византийских армий под командованием Велизария, Нарсеса и Либерия раздором или бранью между самостоятельными = правосубъектными государствами? Ответим: нет, таковой эта борьба не являлась.

Кроме того, уже в архаичные и античные времена сформировалось юридическое понимание существенного отличия между понятием «война» и словосочетанием «ведение боевых / военных действий». Вести «военные действия» в римском праве не было тождественно понятию «война». Последнее могло возникнуть только в условиях формализации межгосударственного вооруженного конфликта. Гражданские войны, часто случавшиеся в республиканском или императорском Риме, включая специфическое понимание римлянами войн с подчиненными им варварами, являлись «ведением военных действий», но не были «войной». Эта терминологическая дихотомия находит много нормативных подтверждений в памятниках римского публичного права [50].
Реконкиста (отвоевание) была направлена на военную ликвидацию бунтов и узурпаций власти самопровозглашенными рексами. По сути, Юстиниан восстанавливал правильный юридический порядок («таксис» [1, с. 46]), существовавший согласно санкциям императоров Зенона Исавра (476-491), Анастасия I (491-518), Юстина I (518-527). Ведь lex foedus даровался восточно-римскими императорами «на конкретные территории» для племенного или войскового («дружинного») пользования конкретных правителей.

Tе физические лица, которые не получали этого права или его подтверждения, соответственно не могли юридически осуществлять власть на территории провинций, де-юре являвшихся неотъемлемой частью Римской империи, персонифицированной политической личностью восточного римского императора [51, с. 1011-1017]. К примеру, Теодорих Великий и его наследники Аталарих и Амаласунта получили официальное разрешение восточных римских императоров называться «рексами остготов» и даже право считаться наместниками Восточной Римской империи на территории западных провинций («Западной части Римской империи») [52, с. 8-10].

Теодат, пленив и убив Амаласунту, самую образованную европейскую женщину VI века, узурпировал власть и таким действием обидел византийского императора - того, кто её назначил королевой и наместницей. В ответ Юстиниан отправил византийскую армию в Италию с целью освободить исконную римскую землю от власти варварского тирана [7, Iord. Getica, 307; 38, Marc. Chron., a. 534; 41, Pauli Diac. Hist. Rom., XVI, 12].

Межгосударственного конфликта в Северной Африке, Италии и Испании в VI веке никак не должно было произойти, поскольку с момента смерти последнего императора Западной части Римской империи 


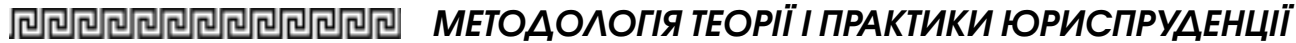

Юлия Непота (480-й год) все бывшие провинции римского Запада, включая Северную Африку и Западную Европу, в полном соответствии с духом и буквой Эдикта Феодосия от 395 г. стали частями, то есть органическими составляющими Восточной Римской империи. Римская империя была, согласно Эдикту Феодосия, единым государством, разделенным на две части ради эффективного управления. Если погибал один из императоров или ситуация делала одну из территориальных частей безвластной, то император второй части становился правителем этой первой части автоматически, без каких-либо дополнительных процедур.

Боевые действия армий Юстиниана в Северной Африке, Италии и Испании были не межгосударственными конфликтами, а военным вмешательством центрального правительства в антиконституционные действия, осуществленные нарушителями имперского порядка. Такие конфликты необходимо считать гражданскими. K примеру, в Италии 535-552 гг. гражданская война была очевидна, поскольку огромное число этнических римлян сражались на стороне остготских королей, а множество остготов и родственных им племён поддержали императора Юстиниана. Уничтожение вандало-алланской армии Гелимера и алеманнско-бургундских войск Бутилина и Левтариса в 553-554 гг. были следствием вооруженного подавления бунтовщиков. Де-юре то же самое произошло в Испании в 552-554 гг.

Важно заметить, что границы императорских владений Юстиниана Великого вышли далеко за пределы максимального расширения Римской империи эпохи принципата Траяна (98-117). И дело не только в широком титуле Юстиниана, то есть в его формальной власти, осуществляемой лишь де-юре, не в огромных личных политических амбициях. «Император Цезарь Флавий Юстиниан, владыка Алеманнский, Готский, Франкский, Германский, Антский, Аланский, Вандальский, Африканский» реально (политически) осуществлял руководство заявленными землями и племенами [53, Procop. HA, XIX, 13]. Следовательно, все конфликты на указанных территориях, случавшиеся между византийскими чиновниками или войсками и местными рексами имели внутригосударственный характер [54, с. 59-92] и были гражданскими конфликтами, но ни в коем случае не являлись официальными межгосударственными войнами.

У статmі детально проаналізовано історико-юридичну проблему cmamycy imnepamopa Cхідної Puмської імперії у VI столітmі. Особливу увагу автор концентруе навколо доктринального питання про необхідність розширення застарілого традиційного історіографічного уявлення про територіальну юрисдикцію владних повноважень східно-римських імператорів.

Синтетичний підхід, побудований на стрункій системі зведеного аналізу великої кількості першоджерел, юридичних норм, імператорських рескриптів, нової фахової літератури, дозволяє небезпідставно стверджувати: протягом всього VI столітmя Західна частина Середземноморського регіону продовжувала визнавати верховну політичну владу «единого» римського імператора - східного. Варварські завоювання, здійснені під час Великого переселення народів, не зруйнували інституиійну базу римської циивілізації. Де-юре ці завоювання були санкціоновані західними та східними римськими імператорами з огляду на застосування ними норми правового режиmy foedus.

Із використанням міждисииплінарного поєднання методологічних принципів класичної історії права 
з останніми хронографічними та фактографічними досягненнями історіографії, загальної теорії політики, історії політичних учень, науки публічного управління та адміністрування автор висуває, відстоюе i аргументовано доводить тезу про здіиснення імператорами Зеноном Ісавром (476-491), Анастасієм I (491-518), Юстином I (518-527) та Юстиніаном Великим (527-565) не лище формального, але й фактичного (політичного) сюзеренітету над колишніми провінціями Західної частини Римської імперіі.

Автор нівелюе стандартне твердження про падіння Римської імперії y V столітті, стверджуючи про неперервність $i$ державно-інституційне продовження існування Iмператорського Риму в ранньому Середньовіччі. Константинополь (де-юре - «Новий Рим») продовжував утримувати верховну правову $і$ політичну владу на теренах Західної Европи, зберігаючи та охороняючи установи $і$ юридичні інститути доби домінату.

Ключові слова: влада імператора, Східна Римська імперія (Візантія), епоха домінату, варвари-федерати, правосуб'єктність варварських середньовічних королівств.

Melnyk V. Political and legal status of the emperor of the Eastern Roman Empire in the VI century AD: title, jurisdiction and subjectivity

The article analyzes in detail the historical and legal problem of the status of the emperor of the Eastern Roman Empire in the VI century $A D$. Particular authorial attention concentrates around the doctrinal issue of the need to revise and expand the outdated traditional historiographic concept of the territorial jurisdiction of power of the Eastern Roman emperors.

The synthetic approach was built up by a consolidated analysis of a large number of primary sources, legal norms, imperial rescripts, new professional literature. It makes it possible to affirm: throughout the VI century $A D$, the Western part of the Mediterranean region continued to recognize the supreme political power of the "single" Roman emperor (eastern). The barbaric conquests during the Great Migration did not destroy the institutional base of Roman civilization. De jure these conquests were even sanctioned by the Western and Eastern Roman emperors, given their application of the rule of law of the lex foedus.

Using an interdisciplinary combination of the methodological principles of the classical history of law and the latest chronographic and factographic achievements of historiography, the author puts forward and defends the argument for the emperor's political suzerainty over the former provinces of the Western part of the Roman Empire.

The author eliminates the standard statement about the fall of the Roman Empire in the $V$ century $A D$, asserting the continuity and state-institutional continuation of the existence of Imperial Rome in the early Middle Ages. Constantinople (de jure "New Rome") continued to maintain supreme legal and political power in Western Europe, preserving and protecting institutions and legal customs of the dominatus era.

Key words: the power of the emperor, Eastern Roman Empire (Byzantium), dominatus era, barbarian foederati, the legal personality of medieval barbarian kingdoms.

\section{Литература}

1. Курбатов Г.Л. Ранневизантийские портреть: $\kappa$ истории общественно-политической мысли. Л. : Издательство Ленинградского университета, 1991. 272 c.

2. Хизер Питер. Восстановление Римской империи. Реформаторы церкви и претенденты на власть. М. : Центрполиграф, 2015. $575 \mathrm{c}$.

3. Prokopios. The Wars of Justinian. Trans. by H.B. Dewing, revised by 


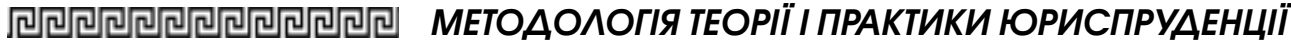

A. Kaldellis. Hackett Publishing Company, Inc., 2014. $642 p$

4. Удальцова 3.В. Италия и Византия в VI веке. М. : АН СССР, 1959. 544 c.

5. Уколова В.И. Империя как «смысл» исторического пространства: попытка политологического анализа, обращенная $\kappa$ прошлому. Власть, общество, индивид в средневековой Европе. М. : Наука, 2008. C. 20-34

6. Kunig I. Aus der Zeit Theoderichs des GroЯen. Einleitung, Text, bbersetzung und Kommentar einer anonymen Quelle. Darmstadt : Wissenschaftliche Buchgesellschaft, 1997. $270 \mathrm{~s}$

7. The Gothic History of Jordanes: in English Version with an Introduction and a Commentary by Charles Christopher Mierow. Merchantville (N.J.), 2006. 188 p.

8. Удальцова 3.В. Византийская культура. М. : Наука, 1988. 288 с.

9. Мельник В.М. Замечания о международной правосубъектности варварских королевств Европы (V - VI века). Альманах міжнародного права. Одеса : ВД «Гельветика», 2019. Bun. 21. С. 3-12.

10. Lot $F$. Les invasions germaniques. La pünütration mutuelle du monde barbare et du monde romain. Paris : Payot, 1945. 334 p.

11. Imp. Iustiniani Novellae (Classic Reprint). Forgotten Books, 2017. 116 p.

12. Миринейский Агафий. О царствовании Юстиниана. Пер., ст. и примеч. М.В. Левченко. М.; Л. : Изд-во АН, 1953. $221 \mathrm{C}$

13. Кнабе Г.С. Корнелий Тацит. Время, жизнь, книги. М. : Наука, 1981. 208 с.

14. Люттвак Эдвард H. Cтратегия Византийской империи. Пер. с англ. А.Н. Коваля. М. : Русский фонд содействия образованию и науке, 2016. 664 с.

15. Gesa M. La politica di Giustiniano verso l'Occidente nel giudizio di Prokopio. Athenaeum. 1981. № 69. P. 389-409.

16. Пигулевская Н. Византия на путях в Индию. М.-Л. : АН СССР, 1951. $410 \mathrm{c}$.

17. Мюссе Люсьен. Варварские нашествия на Европу: германский натиск. пер. с фр. А.П. Саниной. СПб : Евразия, 2008. $400 \mathrm{c}$

18. Мельник B.M. Смена эпох: очерк формирования римско-византийской доктрины международного права (III - VI века). Аннали юридичної історії. Том 2. № 1-2. 2018. C. 63-108.

19. Ballesterosy Beretta A. Historia de Espaca y su influencia sur la civilisacion universale. T. I, Barcelona, 1943. 1053 p.

20. Lex Visigothorum. Visigothic CodeForum Iudicum. 1908 English Translation of Full Text by Samuel Parsons Scott. Link: https: / / libro.uca.edu/vcode / visigoths. htm.

21. Мельник В.М. Розділ 3: Від Риму до Візантії: цивілізація $i$ податки. Навіщо нам податки? Держава як спільний бізнес. Нариси за редакцією Наталіi Ковалко та Віктора Мельника. К. : ТОВ «Якабу Паблішинг», 2019. С. 44-59.

22. Мельник В.м. Римская империя в $V$ веке. Крушение или перерождение? Наука и техника. Нюль, 2019. № $7(158)$. C. 60-66.

23. Семенов В.Ф. История средних веков. М. : Просвещение, 1975. 590 с.

24. Melnyk V.M. Political Byzantinism in the Legal History of Franks. Vestnik of Saint Petersburg University. History. 2020. Vol. 65, Issue 1. P. 228-244.

25. Коньков Д.С. Эврих, предводитель вестготов - друг или подданный: проблема договора 475 года в источниках и исследованиях. Вестник Томского государственного университета. 2014. № 378. С. 125-130.

26. Норвич Джон Джулиус. История Византии. История Венецианской республики. М. : АCT, Астрель, 2011. 960 c.

27. Cregoire de Tours. Histoire des Francs. Ed. by Franzois Guizot. Clermont-Ferrand, 2011, $558 \mathrm{p}$.

28. Мельник B.М. Международно-правовая деятельность франкских королей в первой половине VI века. Юридичний вісник. Юридический вестник. Law Herald. Одеса : Національний університет «Одеська юридична академія», 2019. № 3. C. 182-195.

29. История средних веков. Под редакциией Н.Ф. Колесницкого. М. : Просвещение, 1980. 576 c.

30. Ковальский Ян Веруш. Папы и папство. М. : Издательство политической литературы, 1991. $236 \mathrm{c}$.

31. Уколова В.И. «Последний римлянин» Боэиий. М. : Наука, 1987. 160 c.

32. Codex Justinianus. The Code of Justinian. Translated by Samuel P. Scott (Cincinnati, 1932). Link: https: / / droitromain. univ-grenoble-alpes.fr/Anglica/codjust_ Scott.htm.

33. Удальцова 3.В. Народные движения в Северной Африке при Юстиниане. Византийский временник. 1953. Том VI. Buın. 30. C. 16-48. 
34. Zacharopoulou Effrosyni. Justinian and Theodora: Rivals or Partners in the Christianisation of Nubia? A Critical Approach to the Account of John of Ephesus. Journal of Early Christian History. 2016. Vol. 6. Issue. 3. P. 67-85.

35. Шайо Кристин. Жизнь и духовность восточных православных цееквей. Киев : Дух і Літера, 2013. 624 с.

36. Vussing Konrad. Africa zwischen Vandalen, Mauren und Byzantinern (533-548 n. Chr.). Zeitschrift for Antikes Christentum / Journal of Ancient Christianity. 2010. Vol. 14. Issue 1. S. 196-225.

37. Wilhite David E. Ancient African Christianity. An Introduction to a Unique Context and Tradition. (The late Byzantine era in Africa). Routledge, Taylor \& Francis Group, 2017. 436 p.

38. Marcellinus Comes. Chronicon. Link: https: / / www.thelatinlibrary.com / marcellinus1.html.

39. Ковалко Н.Н., Мельник В.М. Налоговая политика короля Теодориха Великого (493-526) в отношении купеческого сословия Остготского государства. ХІ Міннародна наукова конференція «Історія торгівлі, податків та мита» (26-27 жовтня 2017 року, Дніпро). Тези доповідей. Київ : Iнститут історії НАН України, 2017. C. 12-14.

40. Agnellus Ravennas. Liber pontificalis Ecclesiae Ravennatis. Turnhout: Brepols Publishers, 2006. 393 p.

41. Pauli Diaconi. Historia Romana. A cura di Amedeo Crivellucci. Ristampa anastatica. Torino : Bottega d'Erasmo, 1966. $L I+305 p$.

42. Isidori Historia Gothorum. Historia de regibus Gothorum, Vandalorum et Suevorum. Link: https: / / wrew.thelatinlibrary.com / isidore/historia.shtml.

43. Chronicon Caesaraugustanum Reliquiae. Mommsen T. Monumenta Germaniae Historica. Berlin, 1894. P. 222-223.

44. Циркин Ю.Б. Испания от античности к средневековью. СПб : Филологический факультет СПбГУ; Нестор-История, 2010. 462 с.

45. Корсунский A.P. К вопросу о византийских завоеваниях в Испании VI-VIIвв. Византийский Временник. 1957. Том 12. Buı. 37. C. 31-45.
46. Goubert Paul. L'Espagne byzantine. Administration de l'Espagne byzantine (suite). Influences byzantines religieuses et politiques sur l'Espagne wisigothique. Revue des ütudes byzantines. Annüe 1946. Tome 4. P. 71-134.

47. Тихонравов Е.Ю. Незаконная аннексия территории государства как основание для прекращения его существования. Вестник Томского государственного университета. Право. 2019. № 32. C. 97-106.

48. Lamb Antony. Ethics and the Laws of War. The Moral Justification of Legal Norms. Routledge, 2013. 176 p.

49. Даль В.И. Иллюстрированный толковый словарь живого великорусского языка. Ред. В. Бутромеев. М. : Олма Medua Гpynn, 2014. 448 C.

50. Омельченко О. А. Всеобщая история государства и права. Том 1. М. : Эксмо, 2005. 592 с.

51. Мельник В.M. Право foedus, правовая коммуникация и политическая дезинтеграция Западной Римской империи. География в современном мире: вековой прогресс и новые приоритеты. Сборник статей XIV Большого географического фестиваля. Санкт-Петербург : Институт наук о Земле СПбГУ, 2018. C. 1011-1017.

52. Мельник В.М. Признание верховной власти византийского императора в Остготском королевстве (493-526). Романовские итения - 13 : сборник статей Международной научной конференичии, посвященной 105-летию МГУ имени А.А. Кулешова, Могилев, 25-26 октября 2018 года. Под общ. ред. А.С. Мельниковой. Могилев : МГУ имени А.А. Кулешова, 2019. C. $8-10$.

53. Procopius. The Secret History. Peter Sarris (Editor, Translator, Introduction), G.A. Williamson (Translator). Penguin Classics, 2007. 140 p.

54. Мельник В.М. Византия, германцы и славяне у истоков международной правосубъектности государств: римское юридическое наследие и проблема исторического неравенства возможностей. Аннали юридичної історії. 2017. Том 1. № 2. C. 59-92. 